\begin{tabular}{lrr}
\hline Volume 22 & Nomor 1, Januari 2021 & Halaman 32-40 \\
URL: https://jurnal.unej.ac.id/index.php/SEMIOTIKA/index & E-ISSN: 2599-3429 & P-ISSN: 1411-5948 \\
\hline
\end{tabular}

\title{
RESISTENSI DALAM NOVEL STUDENT HIDJO KARYA MAS MARCO KARTODIKROMO: KAJIAN POSKOLONIAL
}

\author{
THE RESISTANCE IN MAS MARCO KARTODIKROMO'S STUDENT HIDJO: \\ POSTCOLONIAL STUDY
}

\author{
Nando Zikir Mahattir ${ }^{1}$, Novi Anoegrajekti², Abu Bakar Ramadhan Muhamad ${ }^{3 *}$ \\ ${ }^{1}$ Alumni Fakultas Ilmu Budaya Universitas Jember \\ ${ }^{2,3}$ Fakultas Ilmu Budaya Universitas Jember \\ *Corresponding Author: alfi_nh@yahoo.com \\ Informasi Artikel:
}

Dikirim: 30/9/2020; Direvisi: 19/11/2020; Diterima: 1/1/2021

\begin{abstract}
This research uses Mas Marco's novel Student Hidjo as a material object. The Postcolonial theory will be used to analyze Student Hidjo novel's by Mas Marco. Postcolonial is a set of ideas to explore Colonialism's effects in various documents and behaviours, including literature. This study uses qualitative methods to obtain the necessary data from the novel. This type of analysis uses descriptive analysis. The research will use the deconstruction method. It is following postcolonialism which is a reversal of the colonial discourse. Such a technique is useful for reversing the colonial discourse, which presents the relationship between colonizers $><$ colonized in the novel. The study results show the relationship that seemed stable was undermined by the subjectivity of the colonized through their resistance. Postcolonial believe that Colonialism's ambivalent legacy forms much various resistance. The uncertain side occurs because the resulting resistance strikes both sides. On the one side attacking the invaders, but on the other side, shooting resisting subject.
\end{abstract}

Keywords: ambivalent, colonized, colonizers, deconstruction, postcolonial

Abstrak

Penelitain ini menggunakan novel Student Hidjo karya Mas Marco sebagai objek materialnya. Novel tersebut dikaji menggunakan teori poskolonial. Poskolonial merupakan seperangkat teori yang digunakan untuk menelusuri efek kolonialitas dalam berbagai dokumen maupun perilaku, termasuk karya sastra. Penelitian ini menggunakan metode kualitatif untuk mendapatkan data-data yang diperlukan dari novel. Jenis analisisnya menggunakan analisis deskriptif. Sifat dari analisisnya, yaitu dekonstruktif. Hal tersebut sesuai dengan poskolonial yang merupakan pembalikan dari wacana kolonial. Metode yang demikian berguna untuk membalikkan wacana kolonial yang menghadirkan relasi antara penjajah $><$ terjajah di dalam novel. Hasil kajian menunjukkan bahwa relasi yang terkesan stabil tersebut diruntuhkan oleh subjektivitas pihak terjajah melalui resistensinya. Berbagai resistensi yang dihadirkan oleh pihak terjajah dipahami oleh poskolonial sebagai bentuk warisan kolonialisme yang bersifat ambivalen. Sisi ambivalen terjadi karena resistensi yang dihasilkan menyerang dua sisi. Pada satu sisi menyerang penjajah, akan tetapi di sisi lain justru menyerang diri sendiri.

Kata kunci: ambivalensi, terjajah, penjajah, dekonstruktif, poskolonial 


\section{PENDAHULUAN}

Indonesia pernah menjadi koloni negara-negara Eropa. Belanda merupakan negara yang menjajah Indonesia dengan kurun waktu terlama. Belanda tidak hanya menjajah Indonesia dengan senjata, tetapi juga menjajah melalui konstruksi wacana Barat $><$ Timur yang timpang. Mereka menanamkan pemahaman bahwa bangsa Timur itu bangsa yang lemah, inferior, percaya pada takhayul, dan mengutamakan perasaan (Anoegrajekti, 2011:600). Melalui caracara itu Belanda (sebagai Barat) berhasil menguasai tatanan politik, sosial, dan kultural di Indonesia (Timur), sehingga menimbulkan banyak perubahan. Perubahan-perubahan terjadi kecenderungannya membuat penduduk asli (pribumi) yang dicap sebagai "timur" terpinggirkan.

Pada perkembangannya, karena ada protes dari kaum humanis Barat tentang penjajahan Belanda di Indonesia, pemerintah Belanda kemudian menerapkan sistem kolonial baru, yakni politik etis. Politik etis dapat juga disebut politik haluan utama (Mulyono, 1968:99). Politik etis pada dasarnya merupakan upaya perbaikan sistem pemerintahan Belanda di Indonesia berkaitan dengan masalah kemanusiaan dan keuntungan ekonomi. Kebijakan yang diterapkan dalam sistem poltik etis itu meliputi pendidikan (education), pengairan (irigation), dan perpindahan penduduk (emigration) (Susilo dan Isbandiyah, 2018:316).

Kehadiran pendidikan sebagai salah satu mode dalam politik etis, demi perbaikan sistem pemerintahan kolonial, menimbulkan pengaruh signifikan terhadap kondisi kolonialisme di Indonesia. Pengaruh bidang pendidikan ini dapat dirasakan dengan munculnya berbagai organisasi pergerakan seperti Boedi Utomo, Sarekat Islam, Indische Partij, dan masih banyak lagi. Efek lain politik etis dalam bidang pendidikan, yaitu munculnya Balai Pustaka pada 14 September 1908 di Batavia. Balai Pustaka merupakan lembaga penyeleksi bacaan rakyat. Lembaga tersebut dibawahi langsung oleh pemerintah kolonial Belanda. Pihak Balai Pustaka tidak akan menerbitkan bacaan-bacaan yang isinya mengkritik dan bernuansa melawan pemerintah kolonial. Bacaan-bacaan tersebut dianggap sebagai bacaan "liar". Salah satu tokoh pelopor Sastra Indonesia modern yang isi karyanya selalu mengkritisi pemerintah kolonial Belanda, ialah Mas Marco Kartodikromo. Karya-karyanya dianggap liar oleh Balai Pustaka sehingga penerbitannya pun harus di luar Balai Pustaka.

Salah satu karya "liarnya" yaitu novel Student Hidjo (Kartodikromo, 2002) dicekal oleh pemerintahan kolonial Belanda. Novel ini sarat dengan muatan relasi penjajah (coloniser) dengan yang terjajah (colonized). Novel ini menceritakan kehidupan seorang remaja bernama Hidjo yang disekolahkan orang tuanya ke Belanda (Barat-Penjajah). Hidjo mengalami gejolak kultural akibat kondisi kolonial yang dialaminya sebagai pribumi (Timur-terjajah). Sebagai subjek yang terposisikan dalam wilayah bagian dunia terajah, Mas Marco secara transparan menempatkan Barat sebagai pihak dominan.

Disebabkan dominasi Barat itu cenderung dianggap menindas maka hal itu perlu dilawan. Perlawan dalam novel karya Mas Marco itu dilakukan melalui resistensi tokoh Hidjo, yakni dengan menarasikan kultur Timur (terjajah) sebagai kultur yang lebih bermoral dibandingkan kultur Barat (penjajah). Berkaitan dengan upaya perlawanan itu, permasalahan dalam artikel ini diarahkan untuk mempertanyakan bentuk resistensi yang dilakukan tokoh 
Hidjo selaku pihak terjajah, terutama untuk menemukan bentuk resistensi yang ambivalen akibat dari kondisi kolonialisme.

Teori poskolonial jika mengacu pada prefiks "pos" = "pasca" dalam makna "waktu", maka akan menyulitkan pemahaman kritisnya karena kata tersebut lebih berarti "kejadian setelah". Istilah poskolonial terutama, sebagai teori, merambah ke seluruh dunia didasari pada kondisi rakyat-rakyat jajahan yang dulu dijajah kini hidup di mana-mana dengan segala efek yang menyertainya. Oleh karena itu, seluruh dunia merupakan poskolonial (Loomba, 2016:10). Artinya, "poskolonial" bukan sebagai sesuatu yang datang setelah kolonialisme dan menandakan kematian kolonialisme, tetapi harus diarahkan pada sikap kritis, yakni resistensi terhadap dominasi dan warisan-warisan kolonialisme (Loomba, 2016:17). Pernyataan tersebut menunjukkan teori poskolonial berupaya menelusuri efek-efek dari kolonialisme. Efek dimaksud adalah kondisi dan reaksi terhadap wacana kolonial sebagai upaya pihak terjajah memberdayakan diri. Reaksi pemberdayaan dalam dan terhadap wacana kolonial ini dipahami sebagai bentuk resistensi.

Dalam teori poskolonial, pihak terjajah sebagai subjek tertindas dipahami mempunyai kesadaran ganda. Kesadaran ini terikat pada majikan sekaligus yang dapat berkembang menjadi perlawanan (Loomba, 2016:42). Resistensi pihak terjajah merupakan sebuah respon yang menjadikan pihak terjajah tidak lagi sebagai objek, melainkan subjek yang turut mencari penegasan identitas kultural. Resistensi terhadap wacana kolonial, jika tidak disadari maka akan menimbulkan ketergelinciran makna, yakni ketika subjek terjajah menafsirkan wacana dominan dari otoritas kolonial. Kondisi yang demikian dapat dipahami dalam subjektivitas pihak terjajah.

Pembentukkan subjektivitas pihak terjajah di bahas oleh Bhabha dengan menggunakan konsep hibriditas. Bhabha, merujuk kepada gagasan Fanon, menyatakan bahwa liminalitas dan hibriditas merupakan atribut-atribut yang diperlukan dari kondisi kolonial. Identitas kolonial merupakan sesuatu yang selalu berubah, maka muncullah subjektivitas pihak terjajah sebagai bentuk hasrat kolonial yang coba diartikulasikan (Bhabha dalam Loomba, 2016:260). Bhabha menggunakan psikoanalisis yang ditempatkan dengan konteks historis, yaitu konteks kolonial. Individu mulai menyadari perbedaannya melalui peran bahasa. Hibriditas menyebabkan batas antara penjajah dengan pihak terjajah menjadi buram. Maka, pihak penjajah menegaskan perbedaannya kembali melalui stereotip-stereotip (bahasa). Keberadaan stereotip tersebut mengakibatkan wacana kolonial menjadi terbelah, sehingga menciptakan "ruang ketiga".

Bagi Bhabha (dalam Loomba, 2016:261) keberadaan batas dan "ruang ketiga" mengakibatkan ambivalensi yang dapat dibaca bukan hanya sebagai penanda subjek kolonial, tetapi juga sebagai ciri dari kerja otoritas kolonial serta dinamika perlawanan. Dinamika perlawanan yang ambivalen menyebabkannya turut menjadi ambigu dan terbelah.

\section{METODE}

Secara umum, metode yang digunakan untuk meneliti novel Student Hidjo karya Mas Marco berbentuk deskriptif kualitatif. Artinya, metode ini berupaya mendeskripsikan faktafakta data yang bersifat kualitatif (Ratna, 2015:53). Data dimaksud bersifat tekstual narasi dalam novel Student Hidjo karya Mas Marco. Data kualitatif yang didapatkan akan 
dideskripsikan dalam pembahasan atau analisisnya. Dikaitkan dengan teori poskolonial sebagai dasar pijakan analisisnya, maka metode deskriptif kualitatif tersebut bersifat dekonstruktif.

Metode dekontruksi menempatkan sesuatu yang tidak dianggap atau dipinggirkan untuk merobohkan sesuatu yang dominan atau absolut. Dekonstruksi meliputi pembalikan dan penggantian (Sarup, 2008:74). Lebih lanjut Derrida (dalam Sarup, 2008:74) menyatakan tujuan dekontruksi untuk menemukan teks marginal yang menjanjikan, menyingkap, membongkar momen yang tidak dapat dipastikan dengan alat penanda yang pasti, membalikkan hierarki yang ada agar dapat diganti; membongkar agar dapat membangun kembali apa yang selalu telah tertulis. Berpijakan dari penjelasan tersebut, dekontruksi mencoba mencari alternatif lain dari sebuah teks untuk membalikkan fenomena yang terlihat.

\section{HASIL DAN PEMBAHASAN}

Poskolonial merupakan sebuah kritik terhadap wacana kolonial yang menempatkan pihak terjajah sebagai objek yang terpinggirkan dengan segala upaya perlawanannya terhadap pihak penjajah. Hidjo dan Regent Djarak merupakan pihak terjajah (Timur) yang tersubordinasikan oleh kultur penjajah (Barat), sekaligus yang coba melawan (resistensi) dominasi penjajah. Hanya saja, disebabkan kuatnya kultur penjajah yang tertanam dalam kehidupan bangsa jajahan, menyebabkan resistensi tersebut cenderung bersifat ambivalen.

\section{Ambivalensi Resistensi Hidjo}

Kehadiran Betje dapat mewakili standar kehidupan Barat yang diadopsi oleh Hidjo. Betje merupakan produk wacana Barat (penjajah) yang diterima oleh Hidjo sebagai pihak terjajah, sehingga sisi ke-Timuran Hidjo sedikit ditekan. Kondisi Hidjo yang meletakkan keTimurannya dinarasikan ketika Hidjo menginap di hotel dengan Betje.

Hidjo dan Betje naik tram pergi ke Scheveningen.

"Mari kita pergi ke Hotel Scheveningen!" kata Betje kepada Hidjo sambil hatinya berdebar-debar. "Nanti kamu sewa satu kamar dan minta untuk dua orang."

"Baik!" jawab Hidjo kebingungan tetapi mantap.

"Apakah di sini saya bisa dapat kamar untuk dua orang?" tanya Hidjo kepada pelayan hotel, setelah mereka masuk ke hotel.

"Bisa Tuan," jawab pelayan hotel. Dan Hidjo ditunjukkan kamarnya.

Saat itu Hidjo dan Betje langsung masuk ke dalam kamar yang sudah disediakan. Apa yang terjadi selanjutnya di kamar itu, para pembaca bisa memikir atau menduganya sendiri. (Student Hidjo:96)

Situasi tersebut menunjukkan Hidjo meletakkan adab Timur hasil dari pendidikan norma Timurnya. Hidjo menerima kebudayaan penjajah (Barat) yang diberikan oleh Betje. Penerimaan yang terjadi disebabkan oleh perasaan inferior pihak terjajah kepada pihak penjajah karena stereotip yang disematkan. Maka, pihak terjajah akan menjadikan sesuatu yang datangnya dari Barat atau Belanda dalam konteks novel sebagai pusat kebudayaan yang harus diterima, yang turut merubah pola pikir pihak terjajah. Proses yang demikian merupakan proses yang pada akhirnya menghasilkan ketergelinciran makna sehingga wacana kolonial menjadi 
terbelah. Ketergelinciran makna terjadi karena wacana lama yang telah mengendap dan dipertemukan dengan wacana baru.

Ketergelinciran makna tersebut hadir melalui sikap Hidjo yang menyadari perbedaan rasialnya dengan Betje. Identitas-identitas kultural yang hadir melalui atribut-atribut rasial merupakan bentuk representatif dari kultur penjajah dengan pihak terjajah. Kondisi yang demikian dihadirkan dalam novel Student Hidjo karya Mas Marco ketika Betje bertanya tentang perbedaan warna kulitnya kepada Hidjo.

Tuan Hidjo! tanya Betje. "Senang mana Tuan jadi orang Hindia atau orang Belanda?" "Ben je gek Bet," kata mamanya marah mendengarkan kata-kata anaknya. "Nee, Mevrouw!" kalau kulit saya bisa menjadi putih seperti orang Belanda, memang saya senang menjadi orang Belanda," kata Hidjo dengan berani kepada nyonya rumah. "Tetapi karena kulit saya ini bruin (merah tua), baiklah saya jadi orang Hindia saja." (Student Hidjo: 55)

Hidjo menyadari perbedaan rasialnya dengan Betje. Batas tersebut hadir bukan sebagai akhir dari subjektfitas kolonial, tetapi sebagai langkah baru dari subjek kolonial untuk mengidentifikasikan dirinya. Penegasan batas yang diperlukan dalam wacana kolonial, akan menumbuhkan resistensi dari Hidjo. Batas yang menjadi pemisah antara penjajah dengan pihak terjajah merupakan bentuk wacana dominan yang terbelah, bahkan berlipat-lipat. Resistensi yang akan dihadirkan oleh Hidjo merupakan efek dari wacana dominan yang terbelah dan berlipat-lipat tersebut.

Terdapat beragam keterbelahan wacana kolonial yang disadari oleh Hidjo. Keterbelahan wacana kolonial pertama hadir dalam narasi tentang seks pra-nikah yang dilakukannya dengan Betje. Hal tersebut terjadi karena penjajah yang dianggap membawa misi pengadaban justru menampilkan bentuk kultur yang amoral dalam sudut pandang pihak terjajah. Keterbelahan yang kedua, yaitu perbedaan rasial yang diutarakan oleh Betje. Terbelahnya wacana kolonial tersebut karena penjajah selalu menarasikan misi pengadaban dengan membawa kuturnya, tetapi di sisi lain ketika pihak terjajah telah menerima dan menghayati kultur Barat, pihak penjajah malah memberikan garis-garis rasial untuk tetap membedakan mereka (pihak terjajah) dengan dirinya (pihak penjajah). Hal tersebut memang tidak disadari oleh pihak penjajah, tetapi selalu disadari oleh pihak terjajah akibat dari penerjemahan kultur yang telah dilakukan.

Keterbelahan wacana kolonial tersebut membuat peniruan yang dilakukan oleh Hidjo bersifat parsial. Mimikri selalu tidak penuh sehingga dapat mengacaukan wacana kolonial. Mimikri menempatkan Hidjo berada di ruang ketiga, ruang ambang, atau ruang antara yang menjadi penghalang pemersatuan kultur penjajah dengan terjajah.

"Saya harus pulang, kembali ke Tanah Jawa!" kata Hidjo dalam hati sewaktu dia duduk di bawah pohon sambil memandang hamparan laut lepas. "Sebab kalau saya terus belajar di Negeri Belanda ini, barangkali tidak mustahil kalau saya akan terus menjadi orang Belanda, karena saya tentu akan menikah dengan gadis Belanda. Kalau saya sampai melakukan hal itu, saya sama artinya dengan meninggalkan sanak famili dan bangsaku. Bah! Euro peesche beschaving!” (Student Hidjo: 105) 
Kehadiran ruang ketiga dalam bentuk budaya hibrid dapat dilihat dalam narasi data di atas tentang hasrat Hidjo yang ingin kembali ke kultur lamanya. Keinginan Hidjo untuk pulang dan merangkul kepribumiannya, tidak saja menandai kepulangannya secara fisik, tetapi juga menandai resistensinya terhadap kultur penjajah (Barat) yang dibawa oleh Betje. Resistensi itu melibatkan pembacaan identitas sebagai bentuk pertentangan kelas yang dihasilkan oleh kondisi kolonialisme. Hanya saja respon Hidjo tentang pertentangan kelas itu terkesan ambigu, sehingga menimbulkan keinginan untuk meninggalkan kehidupan Barat (penjajah).

Ambivalen resistensi yang hadir dari sikap Hidjo dalam upaya melawan pemikiran Betje, secara representatitif turut menandai penolakannya terhadap kultur Barat. Hidjo melakukan resistensi terhadap Betje yang mengajarinya kultur Barat yakni dengan cara pulang ke Jawa. Kepulangan Hidjo ke Jawa menciptakan kesedihan bagi Betje. Secara sadar Hidjo melawan kultur Barat dengan menegaskan ketidakcocokannya karena kultur Barat dianggapnya tidak memiliki moralitas. Terdapat kesan merendahkan kultur Barat (penjajah) yang dilakukan oleh Hidjo karena menggunakan parameter Timur untuk menilai sebuah moralitas. Resistensi yang dilakukan Hidjo terkesan ambigu, di satu sisi secara sadar dia menyerang kultur Barat karena "amoral" di sisi lain dia balik menindas Betje dengan menciptakan rasa sedih di hati Betje. Sikap resistensi yang yang merendahkan kultur Barat dan menghasilkan penindasan tersebut membuat apa yang dilakukan oleh Hidjo sama seperti apa yang dilakukan oleh penjajah.

\section{Ambivalensi Resistensi Regent Djarak}

Sistem ekonomi kolonial Belanda bersifat dualistik. Terdapat pemisah antara sistem ekonomi modern dengan sistem ekonomi tradisional. Hal tersebut mengalienasi pemimpin lokal, seperti Regent Djarak dihadapan para birokrat kulit putih. Sikap tunduk pemimpin lokal terhadap pejabat Belanda dihadirkan melalui bahasa yang digunakan.

Sesudah para tamu-tamu itu dijamu makan dan minum sepantasnya, lalu Controleur minta izin kepada Regent untuk menandak. Dan Regent, Raden Ayu, Assisten Resident dan istrinya sama mengizinkan permintaan itu dengan senang hati.

"Putra kula mundhut gendhing menapa?" tanya Regent kepada Controleur. "Gambir Sawit!" jawab yang ditanya. (Student Hidjo:77)

Kolonialisme dalam praktiknya turut serta memasukkan unsur bahasa sebagai alat pendukung. Pribumi sebagai pihak terjajah biasanya turut menggunakan bahasa dari pihak penjajah sebagai alat komunikasi. Apabila dikaitkan dengan konteks penjajahan di Hindia Belanda, para penjajah bersikap lain mengenai bahasanya. Bahasa Belanda dilarang digunakan oleh pribumi. Sebenarnya tujuan Belanda tidak memperbolehkan hal tersebut supaya rahasiarahasianya terjaga dan tetap menjaga keterbelakangan pribumi (Lombard dalam Faruk, 2007:36). Maka, penguasa pribumi yang tidak diperkenankan memakai bahasa Belanda, menggunakan bahasa Jawa Kromo Inggil sebagai alat komunikasinya dengan pejabat Belanda. Hal tersebut menunjukkan sebuah kesopanan dan sikap tunduk terhadap Belanda. 
Bahasa Jawa memiliki tiga tingkat tuturan ${ }^{1}$. Bahasa Jawa kromo merupakan tingkat tertinggi dan biasanya digunakan untuk berbicara kepada orang yang lebih tua dan punya keududukan lebih tinggi. Kromo awalnya merupakan ragam bahasa Jawa yang diciptakan oleh bangsawan Jawa. Ragam tersebut digunakan oleh rakyat untuk berkomunikasi dengan penguasa lokal. Penguasa lokal akan merasa sangat dihormati ketika bahasa tersebut digunakan oleh rakyatnya ketika berkomunikasi dengan mereka. Terdapat semacam ketundukkan ketika ragam bahasa tersebut digunakan. Apabila dikaitkan dengan cerita dalam novel, ketundukkan tersebut justru ditunjukkan oleh bangsawan Jawa terhadap Belanda.

Pihak terjajah selain tunduk pada akhirnya turut memberikan respon yang tegas terhadap kolonialisme. Regent Djarak memprotes perbedaan rasial antara penjajah dengan yang dijajah sebagai alat untuk menguasai, meskipun dibalut dengan narasi kesetaraan. Kekuasaan bangsawan Jawa yang dibatasi dengan cara memberikannya gaji, merupakan sebuah bentuk generalisasi dari kelas-kelas berwarna yang diciptakan sebagai pekerja. Regent Djarak dihadapan Belanda yang direpresentasikan oleh conntroleur sama saja statusnya seperti pribumi lain. Persamaan tersebut muncul karena persamaa rasial yang dimiliki oleh Regent Djarak dengan rakyat jelata. Regent Djarak sama saja dengan kusir atau pun wedana karena sama-sama pribumi dan mendapatkan gaji. Istilah "gaji” dan "pribumi” merupakan sebuah istilah yang menjadi identitas dari kelas-kelas pekerja.

Resistensi Regent Djarak terhadap ketimpangan kelas yang dihadapinya dilakukan dengan memprotes narasi persaudaraan antar bangsa yang dibawa oleh controleur.

"Kalau tidak begitu, saya kira akan amat susah bisa menjadi baik perkara associatie (persaudaraan) itu? Lebih-lebih bagi kita orang bumiputera. Itu sangat susah untuk melakukan associatie dengan bangsa Eropa. Karena kebanyakan bangsa Eropa memandang kita sebagai budaknya; kalau menurut pikiran saya. Associatie itu merupakan suatu usaha supaya kita bangsa bumiputera selamanya tetap senang sebagai budak. Sebab orang yang memerintah mau mengaku sebagai saudara kepada kita. Barangkali akan lebih jelas kalau saya sebut associatienya antar majikan dan budaknya." (Student Hidjo: 107-108)

Perkara associatie dianggap oleh Regent Djarak sebagai penciptaan situasi yang hegemonik. Hal tersebut karena persaudaraan antar bangsa akan tetap menghasilkan perbedaanperbedaan rasial yang telah dirasakan oleh Regent Djarak dalam birokrasi kolonial. Persaudaraan antar bangsa yang dibawa oleh controleur menarasikan wacana kolonial yang terbelah. Di satu sisi penjajah merangkul pihak terjajah sebagai kawan atau saudara, di sisi lain perbedaan rasial tetap mengakibatkan persaudaraan tersebut sebagai situasi yang tidak seimbang. Melalaui protesnya, Regent Djarak menyebutkan, bahwa persaudaraan antar bangsa merupakan rencana penjajah untuk menjajah secara halus.

\footnotetext{
1 Tingkat tutur atau unggah-ungguh dalam Bahasa Jawa dibagi menjadi tiga, yaitu ngoko, madya, dan krama. Tingkat tutur ngoko digunakan oleh orang yang sudah akrab. Tingkat tutur yang kedua, yaitu madya digunakan untuk menunjukkan kesopanan menengah dan digunakan oleh orang pedesaan. Tingkat tutur yang terakhir, yaitu krama digunakan untuk orang yang memiliki perasaan segan sebagai bentuk rasa sopan santun terhadap lawan bicara. Tingkat tutur krama biasanya digunakan terhadap orang yang punya status sosial lebih tinggi dari penutur (Poedjosoedarmo dalam Sudarmawan, 2005:29-30).
} 
Pihak terjajah sebagai subjek tertindas, mempunyai kesadaran ganda. Kesadaran yang terikat pada majikan dan kesadaran yang dapat berkembang menjadi perlawanan (Loomba, 2016:42). Regent Djarak sebagai pribumi yang takluk terhadap Belanda menunjukkan posisinya sebagai pihak yang terjajah. Seperti dalam pernyataan Loomba, Regent Djarak memiliki kesadaran ganda, yaitu ketaklukkannya terhadap Belanda dan terdapat pula kesadaran yang berkembang menjadi sebuah perlawanan atau resistensi. Jawaban dari Regent Djarak terhadap pertanyaan controleur tentang sebuah kesetaraan manusia tanpa membedakan rasnya merupakan sebuah bentuk resistensi.

Protes yang dilakukan oleh Regent Djarak melahirkan stereotip-stereotip tentang penjajah yang hanya menganggap pribumi sebagai budak. Pihak penjajah digeneralisasi oleh Regent Djarak, bahwa semua penjajah sama saja dalam memandang pribumi, yaitu sebagai budak. Resistensi dari Regent Djarak di satu sisi memprotes pandangan rasial penjajah terhadap pribumi, tetapi di sisi lain alam bawah sadarnya sedang mengatakan, bahwa jika rasialisme kolonial tidak ada, maka Regent Djarak akan menjadi pihak yang berkuasa karena darah bangsawannya.

Resistensi yang dilakukan oleh Regent Djarak selain menyerang penjajah, tetapi juga menghasilkan bentuk penjajahan baru melalui keinginan bawah sadarnya untuk naik jabatan. Melalui narasi bawah sadar yang demikian, Regent Djarak menciptakan ketimpangan kelas sama seperti yang dihasilkan oleh wacana kolonial. Hal tersebut menunjukkan, bahwa resistensi yang dilakukan bersifat ambivalen.

\section{SIMPULAN}

Novel Student Hidjo karya Mas Marco menghadirkan bentuk penjajahan kultural yang berupa misi pengadaban pihak penjajah terhadap pihak terjajah. Kehadiran penjajah yang mengobjektivikasi pihak terjajah secara kultural, menciptakan situasai yang hegemonik. Pada akhirnya struktur kolonial yang terkesan stabil dan kuat dapat digoyahkan oleh subjektivitas pihak terjajah akibat proses penerjemahan budaya yang melahirkan budaya hibrid.

Hibriditas tersebut menciptakan ruang ketiga yang dimaknai sebagai ruang batas antara dua kultur dari penjajah dengan pihak terjajah. Keberadaan ruang ketiga tersebut mengganggu wacana kolonial karena menciptakan resistensi secara kultural yang sulit dikendalilkan oleh otoritas kolonial. Resistensi yang dilakukan pihak terjajah dapat dipahami menghasilkan sebuah pemaknaan resistemsi yang ambivalensi. Ambivalensi diakibatkan unsur bawah sadar yang menyuarakan sesuatu yang tidak terlihat di dalam teks yang terdapat dalam novel Student Hidjo karya Mas Marco. Dinamika resistensi yang ambivalen dari pihak terjajah merupakan sebuah efek kolonialisme yang dapat dipahami sebagai bentuk warisan budaya kolonial dalam kondisi poskolonialitas.

\section{DAFTAR PUSTAKA}

Anoegrajekti, N. 2011. Retropeksi: Mengangan-Ulang Keindonesiaan dalam Perspektif Sejarah, Sastra, dan Budaya. "Menafsir Keindonesiaan dalam Student Hidjo: Relasi Kuasa dan Kontestasi Global-Lokal". Yogyakarta: Penerbit Kepel Press. 
Faruk. 2007. Belenggu Pasca-Kolonial: Hegemoni \& Resistensi dalam Sastra Indonesia. Yogyakarta: Pustaka Pelajar.

Kartodikromo, M. 2002. Student Hidjo. Yogyakarta: Bentang Budaya.

Loomba, A. 2016. Kolonialisme/Pascakolonialisme. Yogyakarta: Narasi-Pustaka Pramothea.

Mulyono, S. 1968. Nasionalisme sebagai Modal Perjuangan Bangsa Indonesia I. Jakarta: Balai Pustaka.

Ratna, N.K. 2015. Teori, Metode, dan Teknik Penelitian Sastra: dari Strukturalisme hingga Postrukturalisme Perspektif Wacana Naratif. Yogyakarta: Pustaka Pelajar.

Sarup, M. 2008. Panduan Pengantar untuk Memahami Postrukturalisme dan Posmodernisme. Yogyakarta: Jalasutra.

Sudarmawan, H. 2005. "Tingkat Tutur Bahasa Jawa Krama pada Generasi Muda Sinoman di Kecamatan Grogol Kabupaten Sukoharjo”. Skripsi. Surakarta: Universitas Sebelas Maret.

Susilo, A.,dan Isbandiyah. 2018. "Politik Etis dan Pengaruhnya bagi Lahirnya Pergerakan Bangsa Indonesia”. Historia, 6 (2). 